\title{
KERKGESKIEDENIS AS BEGRIP TYDENS DIE KERKHERVORMING
}

PROF. DR. A. D. PONT

\section{Inleiding.}

Met die gegewens wat in ons vaderland beskikbaar is, is dit duidelik dat oor die vraag hoe die reformatoriese vadere die begrip Kerkgeskiedenis verstaan het, daar nog nie veel gepubliseer is nie. Die meeste gegewens wat in hierdie verband beskikbaar is, word gevind in inleidende opmerkings by kerkhistoriese publikasies of as 'n onderdeel van breër monografieë. Dit is egter opvallend dat die Hervorming, soos ook ten opsigte van die ander vakgebiede van die teologie, weer vir die eerste keer na heelwat eeue, die studie van die kerkgeskiedenis gestimuleer het. Daarom is dit wel noodsaaklik dat, al is dit baie vlugtig, "n oomblik na die voor-reformatoriese kerkgeskiedskrywing gekyk sal word.

$\mathrm{Na}$ die Lukaniese geskiedskrywing soos dit in die Nuwe Testament aangetref word, is die eerste werklike kerkhistorikus Eusebius van Caesarea wat ongeveer in die jaar 339 oorlede is. In die jaar 303 het hy sy beroemde Ekklêsiastikê istoria gepubliseer. As gevolg van sy kerkhistoriese arbeid het hy die eretitel, Historiae ecclesiasticae parens, ontvang want feitlik het hy, ten opsigte van sy kerkhistoriese arbeid, geen voorgangers nie. ${ }^{1}$ )

Die hoofmotief van Eusebius se kerkgeskiedskrywing is om die geskiedenis van die Christendom as uitverkore Godsvolk te beskrywe en om dan, as tweede motief, die oorwinning van God oor die duiwel aan te toon. Beide hierdie motiewe word dan aangewend tot die stigting van die leser. ${ }^{2}$ ) Die werk van Eusebius wat uit tien boeke bestaan, begin die kerkgeskiedenis met die behandeling van die Bybelse gegewens, die vestiging van die Christelike gemeente te Jerusalem en die uitbreiding wat dan daarop volg. Sy werk eindig met die beskrywing van die gebeure in die tyd van keiser Konstantyn.

Eusebius se kerkgeskiedskrywing is opgevolg deur die werk van Socrates, Sozomenos, Theodoretus, Philostorgius en Evagrius, om slegs die belangrikstes hier te noem. Hierdie kerkgeskiedskrywing het grotendeels dieselfde karaktertrekke vertoon en was, oor die algemeen, meer die beskrywing van die Christendom, die Godsvolk, as spesifiek die sigbaar-georganiseerde Kerk. Dit moet egter in ag geneem word dat hierdie historici nie 'n baie skerp of duidelike

1) H. U. Meyboom, Kerkgeschedenis van Eusebius Pamphyli, Leiden 1908, bls. II.

2) Vgl. o.a. in hierdie verband W. Nigg. Die Kirchengeschichtsschreibung. München 1934, S. 7-27. 
onderskeid gemaak het tussen die Godsvolg of Christendom as aanduiding van die Christelike geloofsgemeenskap aan die een kant en die Kerk as sigbare, omlynde organisasie aan die ander kant nie.

Dit kan egter gestel word dat Eusebius, wat die vroeë kerkgeskiedskrywing betref, nie alleen die fondamente gelê het nie, maar ook die patroon van die kerkgeskiedskrywing beslissend bepaal het. Of daar so ver gegaan moet word om van ' $n$ bepaalde "kerkhistoriese skool" in hierdie verband te praat, sal die onderwerp van ' $n$ aparte en interessante studie kan word. Daarop kan egter nie nou verder ingegaan word nie.

Hierdie kerkgeskiedskrywing het in die Middeleeue geen besondere navolging gevind nie en daar is gedurende daardie periode ook geen groot, blywende kerkhistoriese werk, wat min of meer dieselfde terrein dek as die vroeëre werke, gelewer nie. Gedeeltelik het dit saamgehang met die feit dat gedurende die Middeleeue in die teologiese denke, die Koninkryk van God met die Kerk gelykgeskakel is. Die resultaat was dat die Middeleeue wel (christelike) geskiedskrywing maar nie kerkgeskiedskrywing in die strikte sin van die woord, oplewer nie. Wat in die Middeleeue aangetref word, is wêreldgeskiedenisse, biografieë en geskiedeniswerke waar die geskiedenis van ' $n$ bisdom, ' $n$ klooster of iets dergliks beskrywe word.

Hoewel in die elfde eeu die hervormingsbeweging binne die Roomse Kerk en die investituurstryd 'n stimulans vorm vir geskiedskrywing met die Kerk as objek, gebeur dit nie. Wat tog gebeur, is dat in verskillende geskrifte die ou, algemene Kerk voorgehou word as die ideale Kerk, die norm waarmee die kerk en clerus van daardie tyd gemeet moes word. Hoewel daar so geen historiese werke na vore kom nie, verskyn daar tog verskillende geskiedenisteologieë ${ }^{3}$ ) wat van die sogenaamde Verfallstheorie uitgaan naamlik dat die kerkgeskiedenis die beskrywing is van die voortgaande verval van die vroeë Kerk wat as die ideaal gewaardeer word. Hierdie studies word egter deur $\mathrm{H}$. Jedin, die moderne Roomse kerkhistorikus, nie as kerkgeskiedskrywing geklassifiseer nie.

Dit beteken dat, afgesien van monografieë oor bepaalde aspekte van die geskiedenis van die Kerk, daar geen werklike kerkgeskiedskrywing van betekenis in die Middeleeue voortgebring word nie. Met die koms van die Hervorming egter vind daar ' $n$ besondere opbloei van die kerkgeskiedskrywing plaas. Gedeeltelik moet dit aan die invloed van die opkomende Humanisme gewyt word wat met sy oproep Ad fontes, die ou kerkgeskiedenisse herpubliseer. So verskyn in 1523 ' $n$ heruitgawe van Eusebius se Historia Ecclesiastica (die Latynse teks) en in 1544 die Griekse teks terwyl

3) Die begrip neem ek oor van $\mathrm{H}$. Jedin, Einleitung in die Kirchengeschichte opgeneem in Handbuch der Kirchengeschichte, Bd. I Freiburg 1963, S. 30. 
Theodoretus se kerkhistoriese werk in 1544 heruitgegee word. Verder word verskillende bronnepublikasies ook nou beskikbaar gestel. Met hierdie materiaal is die moontlikheid om weer 'n oorsigtelike kerkgeskiedenis te skrywe, opnuut geskep.

\section{Reformatoriese Kerkgeskiedskrywing.}

Wanneer oor die kerkgeskiedskrywing en die begrip kerkgeskiedenis by die reformatoriese vadere gehandel word, dan is dit wel so dat van die groot en leidinggewende figure van die Hervorming in Europa met Philippus Melanchton 'n omvattende kerkgeskiedenis geskrywe het. Dit sal dan ook nodig wees om allereers Melanchton se opvattings oor die begrip kerkgeskiedenis na te gaan.

Dit beteken natuurlik nie dat Martin Luther, Johannes Calvyn en Huldrych Zwinglik niks oor die begrippe kerkgeskiedenis of geskiedenis te sê het nie. Maar hulle uitsprake, wat verspreid in hulle geskrifte nagegaan moet word, het vir hulleself nie aanleiding gegee tot die skrywe van kerkhistoriese werke nie. Tog was hulle uitsprake en opvattings oor die kerkgeskiedenis van sodanige belang dat dit ' $n$ belangrike invloed uitgeoefen het. Dit blyk veral uit Matthias Flacius Illyricus se beroemde Ecclesiastica Historia, integram Ecclesiae Christi ideam... secundum singulas centurias perspicuo ordine complectens wat vanaf 1559 tot 1574 by J. Opericus te Basel verskyn het. Hierdie monumentale werk is, jammer genoeg, nooit voltooi nie en het by die dertiende eeu bly vassteek. Vanweë sy indeling het die werk die bynaam Centuriae Magdeburgensis ontvang en dit was nie alleen ' $n$ baanbrekende historiese werk in daardie tyd nie, maar dit het ook groot invloed op die beoefening van die kerkgeskiedenis gehad.

Met hierdie werk en deur die invloed wat uitgegaan het van die uitsprake van die ander reformatoriese vadere kan gekonstateer word dat die Hervorming inderdaad weer die beoefening van die kerkgeskiedenis gestimuleer het en 'n nuwe waarde aan hierdie vakgebied gegee het. Alleen al die werk van Matthias Flacius is die bewys daarvan want dit is 'n eerste poging, na die werk van Eusebius en sy navolgers, om 'n omvattende en volledige geskiedenis van die Christelike Kerk te skrywe. Hoewel die reformatoriese kerkgeskiedskrywing, soos in baie fasette van die Hervorming, teruggryp op beginsels en opvattings wat in die vroeë Kerk gegeld het, is dit hier nie net 'n herhaling van daardie opvattings nie, maar ook die uitbou en verwerking daarvan.

\section{Martin Luther.}

Martin Luther was deur sy baanbrekende werk nie alleen die geniale hervormer van die leer en lewe van die Kerk nie, maar hy het ook die stimulans gegee vir die hernude belangstelling vir die geskiedenis en die kerkgeskiedskrywing. Self het Luther nooit ' $n$ 
historiese studie geskryf nie maar hy het, vanweë sy werk en optrede, 'n besondere waardering vir die historikus en sy werk gehad en sê dan ook daarvan ${ }^{4}$ )

"... die geskiedenis is niks anders as Gods werk nie, dit is ' $n$ beskrywing van sy toorn en genade wat die mens netso seker moet glo as wanneer dit in die Bybel gestaan het. Daarom moet die geskiedenis met die hoogste vlyt, trou en waarheidssin geskrywe word."

Die primêre waarde van die geskiedenis lê dan ook vir Luther in die pedagogiese en illustratiewe momente wat hy daarin vind. ${ }^{5}$ ) Daarby kom dan ook die waarde wat dit vir hom het in sy stryd met Rome en die pous. Saam met en onder invloed van Hieronymus en die Middeleeue aanvaar hy die Verfallstheorie ten opsigte van die kerkgeskiedenis en kom tot die gevolgtrekking dat die verloop van die kerkgeskiedenis ' $n$ ontwikkeling in die Kerk gebring het wat nie aanvaarbaar is nie. Ook as gevolg van hierdie opvatting sien Luther die Roomse pous as die verpersoonliking van die Antichris en in sy stryd teen die pous en die pouslike kerk maak hy volstandig gebruik van historiese argumente.

In sy bekende geskrif Wider Hans Worst (1541) trek Luther die konsekwensies as hy duidelik stel dat die reformatoriese kerk "die rechte alte Kirche sind" want in die reformatoriese kerk word niks gevind wat nie in die ou, regte Kerk ten tye van die apostels te vind was nie. ${ }^{6}$ ) Hier word duidelik dat die reformator 'n ander kerkopvatting het as sy teenstanders en dat dit ook in sy verstaan van die kerkgeskiedenis deurwerk. Dit is moontlik omdat Luther die samehang Gees en Kerk verwerp het en dit vervang het met die korrelasie Gees en Woord. Die Kerk is dus nie, soos by Rome, 'n tweede openbaring van gesaghebbende waarde langs die Woord nie. Daarom staan Luther en met hom die ander reformatore, baie meer krities teenoor die Kerk as wat tot op daardie stadium gebruiklik was. ') Ten opsigte van die sancti patres stel Luther byvoorbeeld in een van sy Tafelredes, getrou aan sy nuwe insig, dat hulle ,.je besser gelebt den geschrieben haben". ${ }^{8}$ )

Juis hierdie kritiese siening van die Kerk beteken dat die kerkgeskiedenis vir Luther ook beskrywing moet wees hoe die Kerk afgewyk het van die regte norme van Gods Woord. Die maatstaf waarvolgens die Kerk in sy geskiedenis beoordeel moet word, is te

4) Vry vertaling van 'n aanhaling gevind by $\mathrm{H}$. Lilje, Luthers Geschichtsanschauung, Leipzig 1932, S. 63, 356-357.

j) W. Nigg, a.a.O.. S. 43.

G) O. Clemen, Luthers Werke in Auswah!, Berlin 1959. Wider Hans Worst, S. 321-378.

7) Vgl. in hierdie geval bv. M. Luther, Von den Konziliis und Kirchen, 1539.

8) O. Clemen, Luthers Werke in Auswahl, Berlin 1962. Bd. VIII, Tischreden 3984, S. 210. In Tischreden 335, S. 44 stel Luther byvoorbeeld In toto Origine non est verbum unum de Christo. 
vinde in die leer van die regverdiging deur die geloof alleen. Daarom verwys Walter Nigg na Luther se opvattings en die kerkgeskiedenisopvatting wat daaruit voortvloei as konfessionele kerkgeskiedenis. ${ }^{0}$ )

By Luther, soos sal blyk by die ander reformatore ook, word sy opvatting van die geskiedenis bepaal deur sy opvatting van die Kerk. ${ }^{11}$ ) In hierdie verband is dit nodig om daarop te let dat Luther, netsoos Calvyn, in sy teologie en denke al die nadruk lê op die allesbeheersende gebeure van die vleeswording, kruisdood, opstanding en hemelvaart van Jesus Christus. Dit beteken dat die geskiedenis nie alleen 'n vaste middelpunt, naamlik Christus, het nie, maar ook ' $n$ einde. Die geskiedenis is dus nie ' $n$ kringloop nie, ${ }^{11}$ ) maar 'n deurlopende gebeure wat deur God gelei word na sy middelpunt en vandaar weer na sy einde, te wete die wederkoms van Christus. Nou is die Kerk die gemeenskap van mense wat rondom die sentrale gebeurtenis van Christus versamel is. Daar, in die Kerk, word die koms en betekenis van Jesus Christus verkondig, uitgelê en toegepas. Die Kerk is dan, volgens Luther se Groot Kategismus van 1529:12)

.... ein heiliges heufflein und gemeine auf erden eiteler heiligen unter einem heubt Christo durch den heiligen geist zusamen beruffen ynn einem glauben synne und verstand mit mancherley gaben doch eintrechtig ynn der liebe on rotten und spaltung."

Hierdie Kerk staan in die wêreld en het 'n taak in die wêreld en dit is om hom in die diens te stel van die Heer van die Kerk in 'n lewe van dankbaarheid in 'n teokratiese bestel. Dit is egter nie die Kerk se taak om ' $n$ bepaalde waarde in die geskiedenis te bewerkstellig nie, soos die Kerk in die Middeleeue 'n oorkoepelende teokrasie wou bou met die pous as sigbare hoof en heer nie, maar om te lewe vanuit die regverdiging deur die geloof, die dankbaarheid teenoor God uit te lewe onder die regering van God.

Kerkgeskiedenis, as begrip, is by Luther dus betreklik eenvoudig. Die taak van die kerkgeskiedenis is om die geskiedenis van die ware Kerk te skrywe. Om die ware Kerk telkens in die geskiedenis terug te vind, moet die norme van die ware geloof aangelê word om daarmee die sigbare kerk te meet. Suiwer historiese opvolging, die historiese suksessie in en van die Kerk, die oudheid dus, is nie die enige waarborg dat die Kerk nog werklik ware Kerk is nie. Wat die ware Kerk is, word dus nie uitsluitlik deur die geskiedenis bepaal nie maar veral deur die belydenis en lewe van die Kerk. Die objek van die kerkgeskiedenis word dus wel die Kerk maar die norme is nie alleen histories nie.

9) W. Nigg, a.a.O., S. 44.

10) E. Emmen, De Geschiedenisw, zardeering der Reformatie, artikel in Geschiedenis, Assen 1944, bls. 112.

11) Vgl. in hierdie verband $\mathrm{H}$. Berkhof, Christus de Zin der Geschiedenis, Nijkerk 1958, blz. $14 \mathrm{vg}$.

12) O. Clemen, a.a.O., Bd. IV, Der Grosse Katechismus, S. 58. 
Hieruit is dit duidelik dat Luther die kerkgeskiedenis sien as 'n teologiese vakwetenskap wat deur die teoloog beoefen moet word omdat die norme wat die kerkhistorikus moet aanlê in die beoefening van sy studie en navorsing teologiese norme is wat deur die Woord van God bepaal word en nie slegs die historiese norme van objektiwiteit, waarheid en derglike meer nie, hoewel laasgenoemdes uiteraard ook deur die kerkhistorikus toegepas moet word.

\section{Philippus Melanchton.}

Die enigste van die groot reformatore uit die Lutherse kring wat hom daadwerklik op die vlak van die kerkgeskiedskrywing beweeg het, was Luther se naaste medewerker, Philippus Melanchton wat die bynaam gedra het van Praeceptor Germaniae. Sy historiese arbeid word sigbaar in sy uitgawe van die Chronica Carionis, 'n Duitse uitgawe in 1532 en 'n Latynse verwerking in 1558.

Cario, 'n natuurwetenskaplike wat aan die hof van keurvors Joachim I geleef en gewerk het, het in 1531 die manuskrip van sy geskiedenis aan Melanchton gestuur met die versoek om dit na te gaan en dit ook te laat druk. Hierdie reeks notas, aantekeninge en hoofstukke is deur Melanchton saamgevat, uitgebrei en volgens die skema van die vier wêreldryke van die boek Daniël, in ' $n$ vaste patroon ingeorden. Hoewel hierdie werk as die Chronica Carionis bekendstaan, is die algemene opvatting dat die grootste deel van die werk van Melanchton self is. ${ }^{13}$ )

In hierdie werk, in sy grotendeels onbekende Voorrede by die geskiedenis van Johannes Cuspinianus van 1541'14) en in ander verspreide opmerkings is dit duidelik dat Melanchton die geskiedenis in die eerste plek sien as ' $n$ middel tot onderwys en opvoeding van die mens. Daarby kom egter die teologiese gesigspunt dat deur die geskiedenisstudie die mens God se werk kan leer ken. Want in die geskiedenis leer 'n mens nie net die wêreldse gebeurtenisse ken nie, maar ook dat God van die begin af die wêreld geskep het én die Kerk en ter wille van die Koninkryk van Christus wêreld en Kerk onderhou. Daarom wil Melanchton nie net in die geskiedenis die gang van die wêreldse gebeurtenisse beskrywe nie, maar veral die gang van die Koninkryk van God. Die leser moet in die geskiedenis die hand van God in die geskiedenis van mense en volke kan sien en die leser moet leer om nie in die eerste plek sy aandag op die menslike bedrywighede te vestig nie, maar om na God se handele te vra. ${ }^{15}$ )

13) R. Stupperich, Der Unbekannte Melanchton, Stuttgart 1961, S. 78.

14) Hierdie Voorrede kom nie voor in die Corpus Reformatorum nie en is herdruk by R. Stupperich, a.a.O., S. 183-191.

15) Vgl. R. Stupperich, a.a.O., S. 78-81. 
In sy Voorrede tot die werk van Cuspinianus stel Melanchton allereers dat geskiedenis geskrywe word vanweë die godsdiens en die wêreldlike ryke sodat die mens kan weet „welches die rechte ware Religion alle zeit gewesen und wie die welt von derselbigen abgewichen"16) en daarby dat die mens kan sien dat ook die wêreldlike regering deur God self ingestel is en hoe daardie owerhede soms gestraf en soms verander is. Die geskiedenis het dus die eerste taak om die mens te lei, ${ }^{1 i}$ )

\begin{abstract}
.... zu dem anfang der Religion und rechten kirche zu bestätigung unsers glauben, dabei auch zu sehen, wie die welt Gottis wort bald veracht und vergessen und greüliche jrthumb angericht und wie für und für denoch Gott sein wort widerumb erwecket und erhalten und hernach dan verheyssener Erlöser, unsern Herrn Jesum Christum, gesandt und das Evangelion in die welt hatt predigen lassen ..."
\end{abstract}

Hieruit blyk wel dat de teologiese gesigspunt die oorheersende is in Melanchton se visie op die geskiedenis ${ }^{18}$ ) en dat dit in die kerkgeskiedenis gaan om die skildering van die ware Kerk, sy leer en inhoud en hoe die ware Kerk geteister word deur valse leringe wat aanslae op die suiwere leer maak ${ }^{19}$ ) asook die oorheersing van die ware Kerk deur kwaadwillige kerklike ampsdraers. ${ }^{20}$ ) Tenslotte sê Melanchton dan ook nog dat die studie en beskrywing van die geskiedenis $k$ an $l e i^{21}$ )

„... zu besserem verstand der heyligen geschrifft. Dabei findet auch eyn Christ mancherle exempel, die jn zu glauben und Gottis forcht vermanen, wie dann in warheyt die Historien eyn schrecklich bild seind Göttliches zorns und gerichtes wider alle laster."

Dit is duidelik dat Melanchton, danksy sy humanistiese agtergrond, die geskiedenis en ook die geskiedenis van die ware Kerk soos dit in die Hervorming weer na vore gekom het, hoofsaaklik vanuit 'n opvoedkundige hoek sien. Melanchton se opvattings oor en in verband met die kerkgeskiedenis is dan ook nie so belangrik nie soos sy optrede waarvolgens die studie van die geskiedenis en die kerkgeskiedenis algemeen in die Duitse skole en aan die Lutherse teologiese fakulteite in Duitsland ingevoer is. Van groot belang is

16) R. Stupperich, a.a.O., S. 185

ii) R. Stupperich, a.a.O., S. 185

18) E. Fueter, Geschichte der Historiograph:s, 1936², S. 187 het al gekla dat Melanchton die geskiedenis volkome aan die teologie onderwerp het. Maar dit moet seker as ' $n$ oordrywing aangemerk word.

19) R. Stupperich, a.a.O., S. 186.

20) R. Stupperich, a.a.O., S. 188

21) R. Stupperich, a.a.O., S. 189. 
verder dat Melanchton prinsipieel onderskei tussen die historia ecclesiastica en die historia politica, die eerste historikus wat hierdie onderskeiding maak."

Volgens Melanchton moet dan in die historia ecclesiastica sowel Gods toorn as Gods genade sigbaar word, terwyl in die historia po:"tica die interpretasie alleen suiwer kan wees indien die kennis van die kerkgeskiedenis daarby kom. Want oor alle kerkgeskiedenis en wêreldgeskiedenis staan God wat die geskiedenis lei en stuur en sy wil deur menslike wesens laat volbring. ${ }^{23}$ )

Saam met Luther lê Melanchton die basis van 'n kerkgeskiedskrywing wat deur Nigg as konfessionele kerkgeskiedskrywing aangedui word. Daarmee wil hy aandui dat die objek, inhoud en doel van die kerkgeskiedskrywing deur die belydenis van die Kerk en sodoende dus ook deur die geloofsbelydenis van die skrywer van die kerkgeskiedenis bepaal word. Tog is dit 'n oop vraag of hierdie betiteling van die reformatoriese kerkgeskiedskrywing korrek genoem kan word. Immers as die kerkgeskiedenis 'n voluit teologiese vak is (en dit kan tog niks anders wees nie) dan sal al die vóór-oordele van die skrywer altyd deur sy teologiese of geloofsopvatting bepaal moet word of deur sy gebrek aan 'n teologiese of geloofsopvatting. Dit lyk buitendien onmoontlik om van a-konfessionele of non-konfessionele kerkgeskiedskrywing deur 'n teoloog te praat want dit sou 'n vanselfsprekende kontradiksie wees.

Die kerkgeskiedskrywing as die Bybels-reformatories is, sal wat sy vóór-oordele én wat die objek, inhoud en doel van die vakwetenskap betref, konfessioneel bepaald moet wees. Dit beteken natuurlik nie dat daarom nie ten volle gewig aan die eise van objektiwiteit, trou aan die waarheid, sorgvuldige hantering van bronne en dergelike meer gegee moet word nie. Dit behoort, in die raamwerk van die kerkgeskiedskrywing, vanselfsprekend te wees. Daarom, so wil dit voorkom, sal dit beter wees as hier na 'n bepaalde soort kerkgeskiedskrywing verwys moet word, om die kerkgeskiedskrywing met 'n histories bepaalde byvoeglike naamwoord te kwalifiseer en van reformatoriese kerkgeskiedskrywing te praat.

\section{Matthias Flacius Illyricus en die Magdeburgse Centurië.}

Matthias Flacius word dikwels aangedui as die "vader" van die reformatoriese kerkgeskiedskrywing hoewel hy, tot aan sy dood in 1575, hom met groot entoesiasme en ywer in die meeste brandende kerklike twiste gewerp het. Sy kerkhistoriese werk begin in 1556 met die uitgawe van sy Catalogus testium veritatis wat bedoel was om aan te toon dat die reformatoriese teologie nie 'n nuwe

22) Vgl. D. Nauta, De Geschiedsbeschouwing der Reformatoren, artikel in De Zin der Geschiedenis, Wageningen 1944, b/z. 155 en 159.

23) W. Nigg, a.a.O., S. 48. 
uitvinding van Luther was nie maar slegs die betuiging van die suiwere Evangelie soos dit ook verstaan is deur 'n groot aantal, oor die vier honderd, getuies van die Waarheid. Hierdie Catalogus was vir Flacius die voorarbeid vir sy veel groter werk waarin hy die geskiedenis van die Kerk vanaf Christus tot die eie tyd wou behandel. In 1553 skryf hy in 'n brief aan Hartman Beyer in Frankfurt dat hy dit beplan om 'n omvattende kerkgeskiedenis te skrywe. In sy brief wys hy dan op die volgende beginsels wat hy daarin wil toepas. Ten eerste moet daar 'n vaste orde, volgens bepaalde tydperke wees. Ten tweede moet hierdie geskiedenis aantoon hoe die Kerk, wat in die aposteltyd in reine eenvoud bestaan het, verval het. As oorsake van die verval noem hy dan die nalatigheid en onkundigheid van die leraars en die boosheid van die goddeloses. Terselfdertyd moet aangetoon word hoe die werk van ware, vrome manne weer die lig van die waarheid helder laat brand het en hoe dit dan weer deur die optrede van goddelose mense uitgedoof is. Tenslotte moet die geskiedenis aantoon hoe deur Gods genade in die sestiende eeu die ware godsdiens weer in al sy suiwerheid herstel is. ${ }^{24}$ )

Omdat hierdie werk vir Flacius alleen te veel was, het hy 'n aantal medewerkers gewerf om hom met hierdie werk by te staan. Vyf uitstaande geleerdes het saam met Flacius 'n span gevorm wat so ver moontlik alle moontlike bronne nagegaan het. Saam met hulle is 'n hele reeks medewerkers, kontroleurs en dergelike aangewys om hierdie groot werk deur te voer.

Die kerkgeskiedenis wat so, onder leiding van Flacius, tot stand gekom het, het ' $n$ vaste orde vertoon. Elke eeu in die kerkgeskiedenis is in 'n afsonderlike band volgens ' $n$ vaste orde behandel. Elke band het uit sestien hoofstukke bestaan wat die volgende vaste inhoud gehad het:

1. 'n Algemene oorsig oor die inhoud van die betrokke band.

2. Die omvang en uitbreiding van die Christelike geloof in die betrokke eeu.

3. Die vervolginge waaraan die Kerk onderwerp is of die beskrywing van die Kerk in die wêreld.

4. 'n Oorsig oor die stand van die leer van die Kerk.

5. 'n Beskrywing van die ketterye en dwalings wat voorgekom het.

6. Die seremonies en gebruike wat in die erediens voorgekom het.

7. Die orde en regering van die Kerk.

8. Skeurings wat in die Kerk voorgekom het.

9. Die kerklike vergaderings en konsilies en hulle besluite.

10. Die lewe, werke en geskrifte van biskoppe en ander skrywers.

11. Die ketters en hulle leer en opvattings.

24) Aangehaal by Wilhelm Preger, Matthias Flacius Illyricus und seine Zeit, Bd. II, 1861, S. 416-417. 
12. Die martelare, hulle lewe en stryd.

13. Die wonders wat voorgekom het.

14. Die geskiedenis van die Jodedom.

15. 'n Oorsig van die heidense godsdienste.

16. 'n Oorsig van die politieke geskiedenis wat vir die kerkgeskiedenis van belang is.

Reeds in die sestiende eeu was daar al besware teen hierdie vaste ordening van die stof wat te veel analities, te min sistematies en weinig oorsigtelik was. Juis die strak hoofstukindeling, wat vir elke eeu dieselfde gebly het, het beteken dat daar geen aandag gogee kon word aan die oorwegend-belangrike wat in elke eeu gebeur het nie. Ook omdat die innerlike samehang tussen die verskillende hoofstukke ontbreek het, was dit duidelik dat hierdie werk tog groot tekortkominge vertoon het. Die feit dat die Magdeburgse Centurieë tot in die agtiende eeu 'n gesaghebbende posisie in die Lutherse kerkgeskiedskrywing beklee het, het tog beteken dat in baie opsigte ' $n$ nadelige invloed so op die vakgebied en die vakbeoefening uitgegaan het. ${ }^{2 \bar{s}}$ )

Tog was hierdie ordening van Flacius en sy medewerkers nie toevallig nie. Want dit gaan vir Flacius primêr daarom om 'n volledige stof- en materiaalversameling van al die gebeure in en om die Kerk in elke eeu byeen te voeg. Dit was dus meer 'n kompilatoriese byeenvoeging en verwerking van al die bronne-materiaal as die daarstelling van 'n historiese kunswerk volgens die maatstawwe van die Humanisme of die antieke. Daarom sê Nigg ook van hierdie werk ${ }^{2 i}$ )

„Diese Sammelmappe, die ein liechtes Finden des gewunschten Materials in jedem Jahrhundert ermöglicht, ist ihnen auf beste gelungen. Es ist ihnen geglückt, die ganze Kirchengeschichte in ein Rubrizierungssystem einzufangen, in welchen alles genau klassifisiert ist. Die Form der Zenturien musz als eine handliche Kartothek gewertet werden, die erlaubt, die grosze Fülle des Stoffes in Uebersichtlichkeit und Klarheit aufzustapeln.'

Daarby moet in gedagte gehou word dat hierdie kerkgeskiedenis geskryf is in die gevaarlike tyd na Luther se dood toe die Roomse Kerk met nuwe krag besiel was en die Protestantisme in Duitsland al meer in die benoudheid geraak het. Hierdie Magdeburgse Centurieë is dus nie net suiwer kerkgeskiedenis nie, maar dit is ook ' $n$ wapen ter verdediging van die Protestantisme. Daarom word die nadruk ook so sterk gelê op die ooreenstemming wat daar na leer en orde bestaan het tussen die reformatoriese Kerk en die

25) Vgl. in hierdie verband Calvyn se indringende kritiek op en afwysing van hierdie ordening in sy brief in 1557 aan Johann Kaspar von Nidbruck. Sien R. Schwarz, Johannes Calvins Lebenswerk in seinen Briefen, Neukirchen o.J. Bd. III, S. 878 .

26) W. Nigg, a.a.O., S. 57. 
oorspronklike apostoliese Kerk. Hoewel getrag word om die geskiedenis van die Kerk so objektief moontlik te skrywe word daar tog terselfdertyd steeds gesoek na die beeld van die suiwere, ware Kerk. Hier kry ons dus 'n kerkgeskiedenis waar die Kerk die objek van die geskiedskrywing is en die norm wat toegepas word om die beeld van die Kerk te kan beoordeel, is die leer van die regverdiging deur die geloof alleen. Die feilbaarheid van die Kerk, vir so ver die Kerk nie leef uit die gehoorsaamheid aan die Heilige Skrif en uit die belydenis van die regverdiging deur die geloof alleen nie, word skerp en duidelik geteken. ${ }^{2 i}$ )

Interessant is dat die leer van die Kerk vir Flacius die swaarste weeg en hulle noem dit dan ook „die edele lig en fakkel van die Kerk". Aan die leer word dan ook die grootste ruimte afgestaan. Hierdie leer vind Flacius in die Nuwe Testament. Die Heilige Skrif is in laaste instansie die norm en maatstaf waarmee elke periode in die geskiedenis van die Kerk beoordeel word. So word in die Voorrede van die tweede deel dan ook gestel, ${ }^{28}$ )

„Er solle aber der gottfürchtige und fleissige Leser dieses eingedenkt sein das man alle folgenden Centurien müsse gegen die erste, als die eine Richtschnur der anderen ist, halten."

Hier word dus kerkgeskiedenis geskryf met die geloofsbelydenis van die Lutheranisme, die Lutherse kerkbegrip, die Lutherse dogmatiek as norm. Vanuit daardie hoek gesien, word die hele geskiedenis van die Kerk gesien as 'n proses van agteruitgang, vervalsing en verrotting van die oorspronklike suiwere Kerk soos dit deur die arbeid van die apostels na vore gekom het. Daarmee word die korrelasie tussen Kerk en Heilige Gees, soos dit by Rome bestaan, totaal verwerp en die korrelasie tussen Heilige Gees en Woord van God op die voorgrond geplaas. Die gedagte van die tradisie van die Kerk wat by Eusebius so in vername rol gespeel het, word hier heeltemal op die agtergrond geplaas. Die oorsaak van die verval van die Kerk word deur Flacius sonder omhaal van woorde vierkantig op die skouers van die pousdom geplaas. Die pous is die verpersoonlikte Antichris wat met die grootste krag bestry moet word.

Hieruit word andermaal duidelik dat die Magdeburgse Centurieë 'n sterk polemiese karakter vertoon. Die geskiedenis word hier gedeeltelik beskou as ' $n$ arsenaal waaruit die skietgoed gehaal moet word om die vyand mee te bombardeer.

Hoewel daar, uiteraard, nie beswaar gemaak kan word teen die feit dat die teologiese voorveronderstelling of vóór-oordeel so 'n bepalende rol speel nie, is dit tog duidelik dat die werk tekortskiet aan objektiwiteit. Die prentjie van verlede wat geteken word,

2i) E. Emmen, a.w., blz. 99.

28) Aangehaal by W. Nigg, a.a.O., S. 59. 
word met skerp lyne alleen swart en wit geteken en dan is, in hierdie siening, die Roomse Kerk sonder uitsondering swart. Aan die ander kant is dit ook duidelik dat in die sestiende eeu, toe die rook van die brandstapels van die Protestantse martelare swart oor Europa gehang het en die wapengekletter van die godsdiensoorloë in toenemende mate gehoor is, dit byna bo-menslik is om te verwag dat 'n reformatoriese teoloog ' $n$ besonder milde of selfs ' $n$ werklik objektiewe oordeel oor die pous en die Roomse vyandelike magte sal kan vel. Juis omdat hierdie stryd in wese 'n stryd is vir die erkenning van die Waarheid moet 'n mens daarmee rekening hou dat die Centurieë die stempel van hulle tyd sal dra. As sodanig is die Centurieë dan ook 'n voortsetting van die oud-christelike kerkgeskiedenis want daar word vasgehou aan daardie bepaalde geskiedbeskouing. Netsoos Eusebius beskou Flacius die ware, Christelike Kerk as 'n onveranderbare, vasstaande grootheid en waarheid. Die geskiedenis van daardie Kerk, of as mens dit so wil stel, die lydensweg van daardie Kerk deur die wêreld moet beskryf word. Daarom kan mens Nigg dit toegee as hy stel: ${ }^{29}$ )

..Die Magdeburger Centurien bedeuten gleich der ganzen Reformation nicht den Beginn der modernen Auffassung, sondern ein Zwischenspiel zwischen der altkirchlichen und der modernen Kirchengeschichtsschreibung."

\section{Johannes Calvyn.}

Wanneer die opvattings van Johannes Calvyn, die grootste sistematikus van die reformasie, die grootste dogmatikus en kerkvader na Augustinus, nagegaan word, dan is dit duidelik dat sy gedagtes oor die kerkgeskiedenis grotendeels in dieselfde lyn lê as wat reeds tot dusver by die ander reformatoriese vadere aangetoon is. Net soos Luther het Calvyn geen suiwer historiese werk gelewer nie en het hy ook nie 'n aparte verhandeling oor die geskiedenis of die kerkgeskiedenis die lig laat sien nie. Sy opvattings lê verspreid in sy geskrifte maar dit is nogtans, so omvattend dat 'n volstandige monografie daaraan gewy kon word. ${ }^{30}$ ) Dit is dan ook nie die bedoeling om hier 'n volledige uiteensetting van Calvyn se opvattings oor die begrippe kerkgeskiedenis, geskiedenis en Kerk te gee nie. Al wat gedoen kan word, is om enkele trekke nader te belig wat sal kan bydra om, saam met die ander stof, 'n beeld te gee van die omvang en inhoud van die begrip kerkgeskiedenis tydens die Hervorming. Ten opsigte van Calvyn kan sy beskouing oor die kerkgeskiedenis onder drie hoofde saamgevat word.

Ten eerste het Calvyn, net soos Luther, Melanchton en Flacius, sy geskiedenisbeskouing grotendeels uit die vroeë Kerk gekry. Uiteraard was dit nie net 'n oorname van daardie gedagtes nie maar

29) W. Nigg, a.a.O., S. 65. 
'n verwerking en ' $n$ selfstandige uitbouing daarvan. Dit beteken dat Calvyn, vanuit die Heilige Skrif, verklaar dat die geheel van die geskiedenis en sy verloop deur God self bepaal word. Dit beteken vir Calvyn dat die geskiedenis bepaal word deur God se regverdige wil en ook die verantwoordelikheid van die mens. Beide staan in dialektiese verhouding tot mekaar. ${ }^{31}$ ) Duidelik word dit by Calvyn dat hy, as hy God sien as die Rigter en Stuurder van die geheel van die geskiedenis, nie bedoel dat die mens in staat is om al Gods handele te verstaan nie. Sonder om die verantwoordelikheid van die mens af te sny, hou Calvyn vas aan die albestier van God en vat dit saam in die paradoksale uitspraak dat in een en dieselfde werk sowel die skuld van die mens as die regverdigheid van God duidelik word. ${ }^{32}$ )

Hiervandaan kom dan die opvatting, in aansluiting by Augustinus, dat die geskiedenis gedomineer word deur die worstelstryd tussen die Koninkryk van God en die ryk van die Satan. Satan wil alles verwoes en die mensdom in verwarring bring ${ }^{33}$ ) en hy dryf die mens om in verset te kom teen die Koninkryk van God. ${ }^{34}$ ) Tog is Satan nie ' $n$ gelykwaardige mag met God nie want hy is aan God onderworpe, hy is niks meer as ' $n$ dienaar of 'n uitvoerder van die toorn van God nie ${ }^{35}$ ) sodat Satan niks meer vermag as wat God hom toelaat nie.

Interessant is dat Calvyn, netsoos Luther, die gedagte verwerp dat die Koninkryk van God met die Kerk gelykgestel kan word. Hierdie Middeleeuse, Roomse opvatting word deur Calvyn met krag afgewys want die Koninkryk van God is grotendeels 'n eskatologiese grootheid. ${ }^{36}$ ) Tog staan die Koninkryk nie buite hierdie wêreld nie maar is dit ' $n$ werklikheid in hierdie wêreld waarby die Kerk ten nouste betrokke is. Met Christus is die Koninkryk gevestig en Hy sal, met die deurwerking van sy Koninkryk, alles weer herstel. Daarom neem Christus en sy Koninkryk die beheersende middelpunt van die geskiedenis in en daarvandaan loop die geskiedenis na die punt waar die Koninkryk van Christus in sy finale ontplooiing geopenbaar sal word. ${ }^{3 i}$ ) Dit beteken terselfdertyd dat die ware Kerk, waarvan Christus ook die hoof is, " $n$ besondere plek in die geskiedenis kry want God lei en beskerm sy Kerk al gaan die weg van die Kerk dikwels deur moeite en gevare. ${ }^{38}$ )

30) H. Berger, Calvins Geschichtsauffassung, Zürich 1955

31) Vgl. in hierdie verband J. Calvinus, Institutio Christionae Religionis I, 17. 18. Asook L. F. Schulze, Calvins Reply to Pighius, Potchefstroom 1971.

32) Institutio 1, 18. 4. Vgl. ook H. Berger, a.a.O., S. $230 \mathrm{ff}$.

33) J. Calvinus, Comm. lob. 1:12 et lob. 2:1.

34) J. Calvinus, Comm. Dan. 10:21-11:2.

35) J. Calvinus, Comm. les. 63:17.

36) J. Bohatec, Calvins Lehre von Staat und Kirche, Breslau 1937, S. 632.

37 Vgl. B. C. Milner, Calvins Doctrine of the Church, Leiden 1970, p. 164.

ss) Vgl. D. Nauta, a.w., blz. 151-153. 
Die Kerk is dan vir Calvyn die gemeenskap van die ware gelowiges wat deur Gods genade tot stand gekom het. In die Kerk geld dan ook ander norme, ander beginsels as in die wêreld want die gelowiges leef uit Gods genade, deur sy Woord, onder sy leiding. Die Kerk word getroos deur die wete dat die wêreld of die Bose die Kerk nie kan vernietig nie, maar terselfdertyd word die Kerk gesien as die kampvegter in die wêreld vir die komende Koninkryk van God. Die Kerk het die taak om God te dien maar as die Kerk dit nalaat kan die Kerk ook die deurwerk van die Koninkryk van God in die wêreld vertraag. ${ }^{39}$ )

Dit is vanuit hierdie gesigshoek dat Calvyn ' $n$ besondere plek toeken aan die strydende Kerk, die nadruk lê op die verantwoordelikheid en vir die gelowige en die Kerk 'n plek inruim as medewerkers van God in die geskiedenis. ${ }^{40}$ ) Vanuit die erkenning dat Jesus Christus die Heer van die geskiedenis is, vanuit die besondere vryheid wat God gee, word die gelowige en die Kerk tot medewerking geroep. Die gelowige is immers deur Jesus Christus verlos van die knegskap aan die sonde en sy stryd is, deur die oorwinning van Christus, sinvol omdat dit nie alleen oefening van die geloof is nie, maar ook die uitlewing van die dankbaarheid. So roep die geloof 'n paradoks na vore: die gelowige het deel aan die oorwinning van Christus maar tegelykertyd word hy blywend tot stryd geroep teen die magte van die Bose. Die weerbare diens van God is, as dit so gestel mag word, die keersy van die genade. ${ }^{41}$ )

Deur so aan die gelowige en die Kerk 'n relatiewe selfstandigheid te gee, maak Calvyn die Kerk ook deelgenoot van die historiese ontwikkeling. Maar dan bly Kerk en gelowige nooit meer as instrument en medewerker van God in die volvoering van sy plan en wil nie. Daarom wys Calvyn die oordrewe heldeverering in die geskiedenis af deur daarop te wys dat ook die helde alles aan God te danke het. ${ }^{42}$ )

By Calvyn word die kerkgeskiedenis voluit as teologiese vak beskou waar die begrippe Kerk en geskiedenis, afsonderlik en gesamentlik, omlyn en bepaal word deur die Woord van God en die belydenis van die Kerk. Tog is dit ook waar dat die begrip Kerk, as objek van die kerkgeskiedenis, by Calvyn nie 'n enkelvoudige begrip is nie. Daarvoor hoef mens slegs die Institutio na te gaan of die Kategismus van Genève, Afd. 15-16, Vrae 92-100 waar die begrip Kerk die betekenis het van „die gelowiges wat deur God tot die ewige lewe bestem is;" die "liggaam van Christus;" en die

\footnotetext{
39) H. Berger, a.a.O., S. 133-134.

$40)$ E. Emmen, a.w., blz. 119.

41 J. Calvinus, Institutio, III, 7-9.

$\left.{ }^{12}\right)$ J. Calvinus, Comm. in Sam. II, 5:10.

43 D. Laing. The Works of John Knox. Edinburgh 1846, Vol I, p. XXVIII.
} 
„sigbare, strydende Kerk op aarde". In die kerkgeskiedenis moet al hierdie momente, wat onlosmaaklik met die begrip Kerk verbind is, verdiskonteer word.

\section{John Knox.}

Die Skotse hervormer, John Knox, wat in baie opsigte 'n direkte leerling van Calvyn genoem kan word, het aan die einde van sy lewe hom gewy aan die beskrywing van die geskiedenis van die Hervorming in sy vaderland. Hierdie The History of the Reformatioun of Religioun within the Realme of Scotland bestaan uit vyf boeke wat geskryf is gedurende die jare 1559-1571. ${ }^{43}$ ) Dit is die eerste keer in 'n onvolkome uitgawe gepubliseer in 1586. Die eerste volledige uitgawe het egter eers in 1644 in Londen en Edinburgh verskyn. Die karakter van hierdie kerkgeskiedenis word al in die voorwoord van Knox verduidelik as hy verwys na die donker wolk van die Roomse Antichris wat ook oor Skotland gelê het maar wat nou, deur die genade van God verdryf is. ${ }^{44}$ )

„... that, in despyte of Sathan, hipochrisye is disclosed, and the trew wyrschipping of God is manifested to all, ...." Ook hier word die geskiedenis van die Kerk gesien teen die groot agtergrond van die worstelstryd van die magte van die Antichris teen die Koninkryk van God. ${ }^{45}$ ) Die Roomse Kerk word dan beskryf as die laagtepunt van die verval wat die ware gelowiges in gevangenskap hou. Daarenteen is die reformatoriese Kerk die een, ware, heilige Kerk waar die mens weer die geleentheid kry om God te dien en te eer na die eis van die ,playne Word of God... ${ }^{46}$ ) Die stryd om die herstel van die een, ware en heilige Kerk is vir Knox die tema van sy geskiedenis.

Hier word dus nie 'n omvattende algemene Kerkgeskiedenis gebied nie maar slegs 'n onderdeel van die totale geskiedenis van die Kerk en dan wel dié deel waarin die Kerk in Skotland, na die eis van Gods Woord, hervorm is. Hierdie hele geskiedenis word bepaal deur Knox se gehoorsaamheid aan die Woord van God, sy teologie en sy geloof. Dit sou egter 'n totale misverstaan van Knox se werk wees om dit as 'n apologia pro vita sua te beskou. Inteendeel dit gaan hier, soos by die ander reformatore, om die aanduiding van Gods handele in die geskiedenis van die mens waar die mens en die ware Kerk niks meer is as die instrument in die hand van God nie. ${ }^{47}$ )

44) D. Laing, I.c., p. 3.

45) D. Laing, l.c., p. 4-5.

46) P. J. Kromsigt, John Knox als Kerkhervormer, Utrecht 1895, blz. 358-359.

ii) P. J. Kromsigt, a.w., blz. 322-323. 


\section{Slotopmerkings.}

Die begrip kerkgeskiedenis skep vir die reformatoriese vadere geen besondere probleme nie. Dit is vir hulle, soos aangetoon, die gebeure soos dit op hierdie ondermaanse wêreld plaasvind in die patroon van die kosmiese stryd van die magte van Satan teen die Koninkryk van God. Dit is egter 'n stryd waar by die kruis en opstanding van Jesus Christus die oorwinning reeds deur die Koninkryk van God behaal is. Daarna is die magte van die Satan verslane magte wat met die resterende kragte wat hulle nog het, voor hulle finale vernietiging met die wederkoms van Christus, trag om die Koninkryk van God te dwarsboom. Dit is egter prinsipieel onmoontlik dat die magte ooit oor die Koninkryk van God of oor die Kerk kan triomfeer.

In hierdie kosmiese stryd staan die gelowige, geroepe mensdom en die Kerk vierkantig teenoor die Antichristelike magte. Die kerkgeskiedenis is die verhaal van die Kerk en sy deelname aan daardie stryd, sy neerlae en sy suksesse. Die objek van die kerkgeskiedenis is die ware, suiwere, heilige Kerk soos dit in die reformatoriese teologie omskryf word en soos dit in die strydende Kerk in die wêreld sigbaar word. Die dogmaties-leerstellige inhoud wat aan die begrip Kerk gegee word vanuit die reformatoriese teologie, oorheers dus die geskiedskrywing.

Dit beteken dat dit in die kerkgeskiedskrywing gaan om die ware Kerk en dit sluit dus die Roomse Kerk, die Anabaptiste, die sektariërs, vrydenkers en heidene onmiddellik uit. Dit wil sê in diê sin dat daardie groepe nie beheersend in die middelpunt van die aandag staan nie. Hierdie opvatting hang saam met die prinsipiële uitgangspunt van die Hervorming dat die reformatoriese Kerk die herstel, die weer-oprigting is van die ware, suiwere Kerk van die aposteltyd wat geleidelik, deur die loop van die geskiedenis, deur die pouse op allerlei dwaalweë gelei is. In aanknoping en uitbreiding van die gedagtes van Eusebius en Augustinus word die geskiedenis van die ware Kerk as organisme en instituut beskryf en word alles wat daarteen bots as verwerplik en bestrydenswaardig beskou. Kerkgeskiedenis ten tye van die Hervorming is voluit 'n teologiese vak. Hierdie feit word miskien die beste onderstreep deur die gegewene dat Matthias Flacius Illyricus in Wittenberg professor in die Ou Testamentiese en te Jena professor in die Nuwe Testamentiese wetenskap was! Daarom domineer die teologiese voorveronderstelling en solank die kerkgeskiedenis 'n teologiese vak bly, sal dit nie anders kan wees nie. Nauta is dan ook korrek as hy stel: ${ }^{48}$ )

48) D. Nauta, a.w., blz. 160. 
„Ook wij zullen steeds weer moeten trachten bij de geschiedsbeschouwing der reformatie aan te knoopen... om vast te houden den rijkdom, dien de reformatie in principieel opzicht ons heeft overgeleverd..."

Dit beteken nie dat ons daarmee al die probleme van die kerkgeskiedenis of van die kerkgeskiedskrywing van ons eie tyd klaar opgelos het nie, maar dit is seker 'n suiwerder, Skriftuurliker weg om te gaan as om kerkgeskiedenis te probeer beoefen soos dit in die negentiende eeu beoefen is of soos dit vandag, in sommige gevalle, onder invloed van die moderne liberalisme en sosialisme beoefen word. 